\title{
The ICT Competency MOOCs for Teachers in Russia
}

\author{
Marina S. TSVETKOVA \\ Academy of Improvement of Professional Skill and Professional Retraining of Educators \\ 8 Golovinskoe Shosse, Moscow 125212, Russian Federation \\ e-mail:ms-tsv@mail.ru
}

\begin{abstract}
The experience of the formation of the framework of ICT competences for teachers on the basis by UNESCO Institute for Information Technologies in Education (IITE) research and dissemination of the experience of the MOOC in Russia for the development of ICT Competency teachers for digital education.
\end{abstract}

Keywords: digital education, massive open online course, ICT competency for teachers.

\section{Introduction}

The UNESCO Institute for Information Technologies in Education (IITE) (UNESCO, 2016a) was established as an integral part of UNESCO by the General Conference of UNESCO at its 29th Session (November 1997, Moscow, Russian Federation). At the same session, the Statutes of IITE were adopted.

According to its Statutes, the Institute contributes to the design and implementation of the programs of the Organization regarding the application of information and communication technologies in education. It is principally program-driven, responds to both global and country needs is a part of an operational network of UNESCO structures and supports the achievement of the strategic objectives of the Medium-Term Strategy as well as the program priorities of UNESCO, as approved by the General Conference.

IITE's mission is to serve as a center of excellence and provider of technical support and expertise in the area of ICT usage in education in the world.

The results of international analytical studies 2003-2013 published in the open access place in the electronic library IITE (UNESCO, 2016b), the countries of experience in the integration of new ICT into the education system regarding the information environment of globalization presented in the book "ICT in Education" (Badarch, 2013) (Fig. 1). 


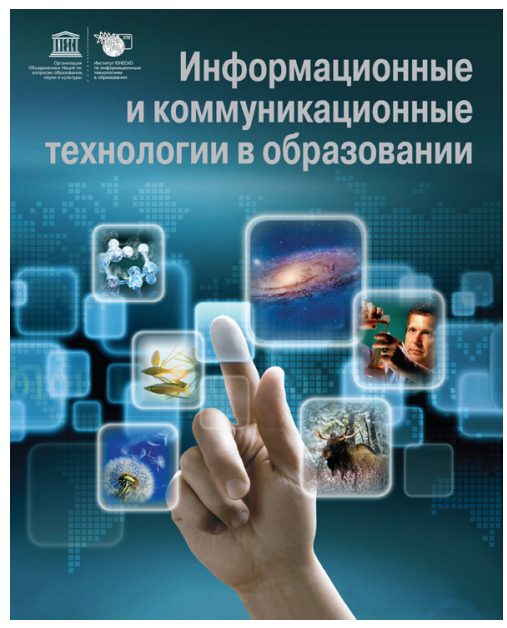

Fig. 1. The book "Information and Communication Technologies in Education".

\section{The ICT Competency Framework for Teachers: UNESCO ICT-CFT}

One key lesson is to acknowledge the many facets that ICT in Education policies have to tackle such as teacher competencies, learning materials, ICT equipment, student and teacher motivation, as well as the linkages to other areas of national policy and socioeconomic development. Adopting a cross-sectoral approach through an ICT in Education Master Plan help countries to address all relevant dimensions.

In this context, the ICT Competency Framework for Teachers is aimed at helping countries to develop comprehensive national teacher ICT competency policies and standards, and should be seen as an important component of an overall ICT in Education Master Plan.

The current version of the ICT Competency Framework for Teachers is a 2011 update of the original version published in 2008 and is the result of the partnership between UNESCO and CISCO, INTEL, ISTE, Microsoft. In this version, the Framework has been enriched on the basis by feedback from subject matter experts and users worldwide and enhanced with the inclusion of example syllabi and exam specifications for Technology Literacy and Knowledge Deepening (Midoro, 2013).

The ICT Competency Framework for Teachers (UNESCO ICT-CFT) were developed in 2008 and improved in 2011 by the UNESCO cross-sectoral working group based on consultations with experts in the field from all world regions. The aim of the Framework is to support the UNESCO Member States in developing national (regional) policy on teachers' ICT competence and establishing the standards in this field. The Framework has been enriched using feedback from experts and users worldwide.

The Russian version of ICT-CFT was presented by the UNESCO Institute for Information Technologies in Education (IITE) in December 2011 (UNESCO, 2011). 
Three approaches to human capacity development The Framework is based on the hypothesis that education can contribute to the development of a country's economy and society. The country can develop from one that uses ICTs (phase 1), to one that has a high-performance workforce (phase 2), and finally to one with a knowledge economy and information society (phase 3 ). These three phases serve as a basis for three complementary and somewhat overlapping approaches that connect education policy with economic development. The teachers' professional profile in ICTs develops following an analogous path: the professional levels are isomorphic to the national development goals, see table (Fig. 2).

\section{Structure of UNESCO ICT-CFT}

Six aspects of the teachers' activity/praxis The ICT-CFT assumes that there are six main aspects of the teacher's activity: understanding the ICT role, curriculum, pedagogy, ICTs, organization, and professional development. The framework of 18 modules reflects the

\begin{tabular}{|c|c|c|c|}
\hline $\begin{array}{l}\text { Development } \\
\text { stages }\end{array}$ & Economy & Education & Approach \\
\hline $\begin{array}{l}\text { Capital Deepening: } \\
\text { Use of ICTs }\end{array}$ & $\begin{array}{l}\text { The ability of the workforce } \\
\text { to use equipment that is } \\
\text { more productive than earlier } \\
\text { versions }\end{array}$ & $\begin{array}{l}\text { Increase the extent to which } \\
\text { new technology is used by } \\
\text { students, citizens, and the } \\
\text { workforce by incorporating } \\
\text { technology skills into the } \\
\text { school curriculum. }\end{array}$ & Technology literacy \\
\hline $\begin{array}{l}\text { Higher Quality Labour: } \\
\text { High-performance } \\
\text { workforce }\end{array}$ & $\begin{array}{l}\text { A more knowledgeable } \\
\text { workforce that is able to add } \\
\text { value to economic output }\end{array}$ & $\begin{array}{l}\text { Increase the ability of } \\
\text { students, citizens, and the } \\
\text { workforce to add value to } \\
\text { society and the economy } \\
\text { by using knowledge and } \\
\text { applying it to solve complex, } \\
\text { real-world problems }\end{array}$ & Knowledge deepening \\
\hline $\begin{array}{l}\text { Technological innovation: } \\
\text { Knowledge economy and } \\
\text { information society }\end{array}$ & $\begin{array}{l}\text { The ability of the workforce to } \\
\text { create, distribute, share, and } \\
\text { use new knowledge. }\end{array}$ & $\begin{array}{l}\text { Increase the ability of } \\
\text { students, citizens, and the } \\
\text { workforce to innovate, } \\
\text { produce new knowledge, } \\
\text { and benefit from this new } \\
\text { knowledge. }\end{array}$ & Knowledge creation \\
\hline
\end{tabular}

Fig. 2. Matching of the UNESCO ICT-CFT approaches and stages of the socio-economical development of the society. 
interrelation of the three approaches (technology literacy, knowledge deepening, knowledge creation) to teaching based on human capacity development with the six aspects of the teachers' work (understanding the ICT role, curriculum, ICTs, organization, and professional development) (see Fig. 3).

\section{SECTION 1. PRELIMINARY QUESTIONS ON THE USE OF ICTS}

1. What is your teaching position?

a Kindergarten Teacher/ b. Lower Primary Teacher/ c. Upper Primary Teacher/ d. Primary Teacher Specialist (e.g., Music or Languages)/ e. Lower Secondary Teacher/ f. Secondary Teacher/ g. Special Education Teacher/ h. Other (specify)

2. What is your subject matter?

a. Language/ b. Mathematics/ c. Science/ d. Society and Environment/ e. Physical Education/ f. Arts/ g. Technology/ h. Economics/ i. Language/ j. Other (specify).

3. How many years have you been working in schools?

a. 0 to 1 year/ b. 2 to 3 years/ c. 4 to 5 years/ d. 6 to 9 years/ e. 10 to 19 years/ f. 20 years or more.

4. Is your school in a remote area?

a. Yes/ b. No

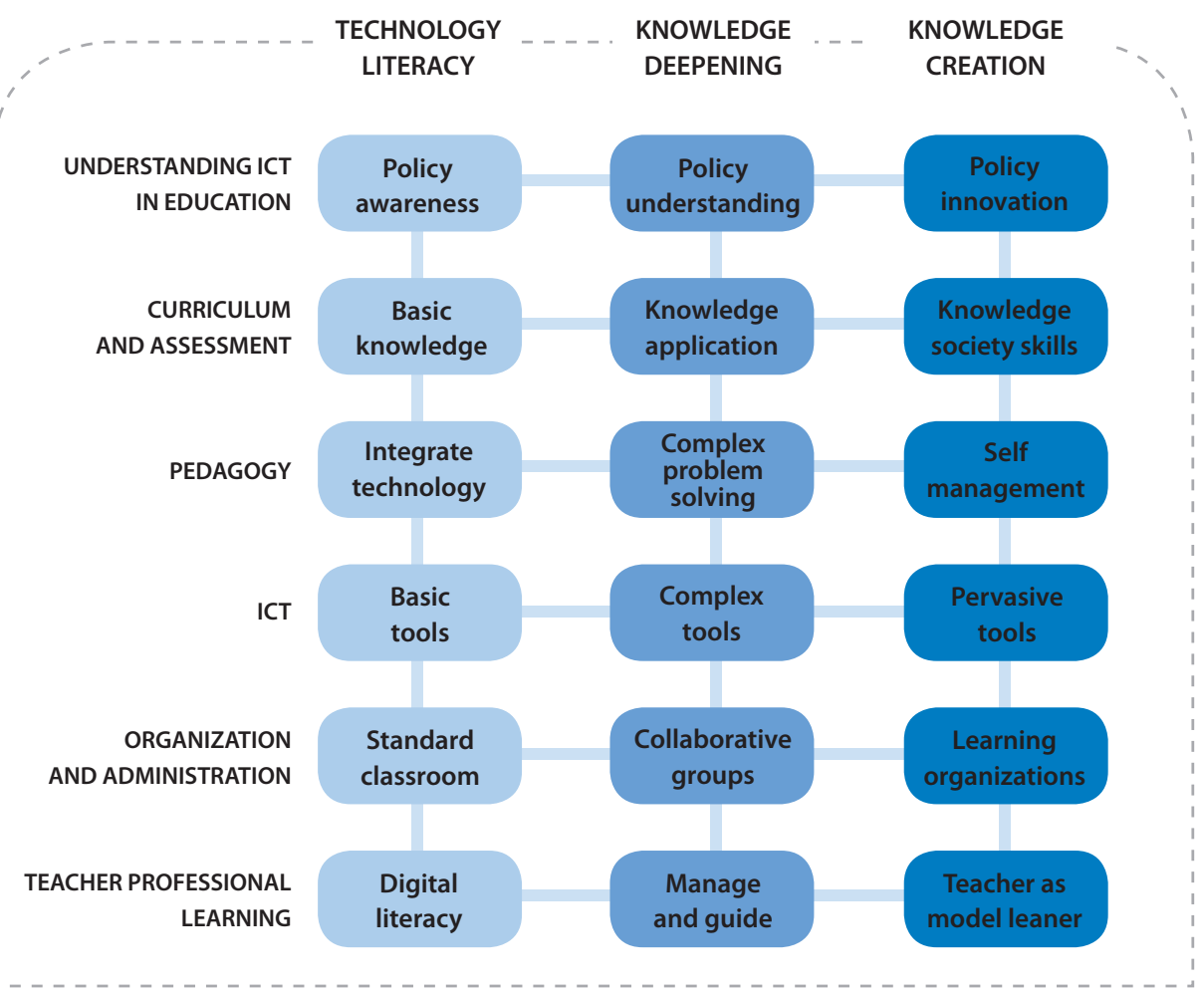

Fig. 3. Structure of UNESCO ICT-CFT. 
5. What is your gender?

a. Male/ b. Female

6 . In which age group do you belong?

a. Less than 24 years/ b. 25 to 29 years/ c. 30 to 39 years/ d. 40 to 49 years/ e. 50 to 64 years/ f. 65 years and over.

7. Can you use a computer?

a. Yes/ b. No

8. How frequently do you use a computer?

a. Daily/ b. Weekly/ c. Monthly/ d. At least once a term/ e. Never.

9. Do you have a computer at home?

a. Yes/ b. No

10. Do you have an Internet access at home?

a. Yes/ b. No

11. Can you use a computer at school?

a. Yes/ b. No

12. Do you have an Internet access at school?

a. Yes/ b. No

13. Are there other places where you can use a computer and access the Internet (Internet cafes, libraries, etc.)?

a. Yes/ b. No

If the answer to question 7 is "b" or the answer to question 8 is " $\mathrm{e}$ ", then the test is over.

\section{Teachers ICT Competency}

Otherwise, the teacher must complete Section 2 below. Section 2 has the same structure as the UNESCO ICT-CFT. The correctness of the answer to each item has to be determined by local experts once the questionnaire is localized since its validity could depend on local conditions.

Each question provides only select one answer.

\section{SECTION 2.}

UNIT 1. "TECHNOLOGY LITERACY"

\subsection{UNDERSTANDING ICTS IN EDUCATION: POLICY AWARENESS}

1. Is there a policy for introducing ICT in the school in your country? a. Yes/ b. No/ c. I don't know

2. If the answer to question 1 is Yes, this policy is at:

a. National level/ b. Regional level/ c. School level/ d. I don't know

3. Would you be able to describe how this policy is implemented in your school?

a. Yes/ b. No/ c. I don't know 
4. Would you be able to describe the positive aspects and weaknesses?
a. Yes/ b. No/ c. I don't know

5. Indicate the extent to which you agree or disagree with each statement about ICTs:

a. Students' use of ICTs can support student-centered learning (strongly agree, 1, 2, 3, 4, 5, strongly disagree)/

b. ICTs provide valuable resources and tools to support student learning (strongly agree, 1, 2, 3, 4, 5, strongly disagree)/

c. ICTs can be mainly used for efficient presentations (strongly agree, 1, 2, 3, 4, 5, strongly disagree)/

d. ICTs has limited capacity to provide benefits in the classroom (strongly agree, $1,2,3,4,5$, strongly disagree)

\subsection{CURRICULUM AND ASSESSMENT: BASIC KNOWLEDGE}

1. To what extent do you use ICTs with your students in the context of your discipline? (no, 1, 2, 3, 4, 5, large)

2. Have you ever used educational software related to your subject matter? a. Yes/ b. No

3. To what extent do you use educational software related to your subject matter with your students? (no, 1, 2, 3, 4, 5, large)

4. To what extent do you use digital artifacts from student assignments as evidence of student achievement? (no, 1, 2, 3, 4, 5, large)

5. 5. To what extent do you use ICT applications to monitor, evaluate, and report on student achievement? (no, 1, 2, 3, 4, 5, large)

\subsection{PEDAGOGY: INTEGRATE TECHNOLOGY}

1. To what extent do you use presentation software in your lessons? (no, 1, 2, 3, 4, 5, large)

2. Do your students use ICTs for mastering skills just taught?
a. Yes/ b. No

3. To what extent do you use digital resources in your lessons? (no, 1, 2, 3, 4, 5, large)

4. Do you design lesson plans incorporating digital resources? a. Yes/ b. No

5. To what extent do you share your experience of ICT use with other teachers? (no, 1, 2, 3, 4, 5, large)

\subsection{ICTS: BASIC TOOLS}

1. To what extent do you use a word processor? (no, 1, 2, 3, 4, 5, large)

2. To what extent do you use presentation software? 
(no, 1, 2, 3, 4, 5, large)

3. To what extent do you use a web browser?

(no, 1, 2, 3, 4, 5, large)

4. To what extent do you use a search engine?

(no, 1, 2, 3, 4, 5, large)

5. To what extent do you use an email address?

(no, 1, 2, 3, 4, 5, large)

6. To what extent do you use some course?

(no, 1, 2, 3, 4, 5, large)

7. To what extent do you use open educational resources?

(no, 1, 2, 3, 4, 5, large)

8. Do you use the computer to record grades, maintain student records, or to take students' attendance?

a. Yes/ b. No

\subsection{ORGANISATION AND ADMINISTRATION: STANDARD CLASSROOM}

1. To what extent do you integrate the use of a computer lab in the teaching activities?

(no, 1, 2, 3, 4, 5, large)

2. To what extent do you use ICTs in the classroom?

(no, 1, 2, 3, 4, 5, large)

3. To what extent do you use ICTs with your students for presentations, without altering the classroom setting?

(no, 1, 2, 3, 4, 5, large)

4. To what extent do you use ICTs in the classroom for individual study?

(no, 1, 2, 3, 4, 5, large)

5. To what extent do you use ICTs in the classroom for small group activities?

(no, 1, 2, 3, 4, 5, large)

\subsection{TEACHER PROFESSIONAL LEARNING: DIGITAL LITERACY}

1. To what extent do you use digital resources to enhance your school productivity?

(no, 1, 2, 3, 4, 5, large)

2. To what extent do you use digital resources to learn about your subject matter? (no, 1, 2, 3, 4, 5, large)

3. Have you ever used ICTs to access online courses?

a. Yes/ b. No

4. Could you list at least three of the main Internet issues related to ethics?

a. Yes/ b. No

\section{UNIT 2. "KNOWLEDGE DEEPENING"}

\subsection{UNDERSTANDING ICT IN EDUCATION: POLICY UNDERSTANDING}

1. To what extent do you think that ICTs could change the school?

a. (no, 1, 2, 3, 4, 5, large)/ b. I have no precise idea 
2. To what extent do you credit policy for introducing ICTs in the school in your country?

a. (no, 1, 2, 3, 4, 5, large)/ b. I have no precise idea

3. To what extent has this policy changed your practice in the classroom?

a. (no, 1, 2, 3, 4, 5, large)/ b. I have no precise idea

\subsection{CURRICULUM AND ASSESSMENT: KNOWLEDGE APPLICATION}

1. To what extent do you use ICTs with your students to understand real-world problems?

(no, 1, 2, 3, 4, 5, large)

2. Have you ever used web 2.0 for learning assessment?

a. Yes/ b. No/ c. I do not fully understand the question

3. To what extent do you use innovative ways of assessment using ICTs?

a. (no, 1, 2, 3, 4, 5, large)/ b. I do not fully understand the question

4. To what extent do you help students apply knowledge obtained in your class in real-world situations?

(no, 1, 2, 3, 4, 5, large)

\subsection{PEDAGOGY: COMPLEX PROBLEM SOLVING}

1. To what extent do you adopt collaborative learning in the classroom? (no, 1, 2, 3, 4, 5, large)

2. To what extent do you adopt project-based learning in the classroom? (no, 1, 2, 3, 4, 5, large)

3. To what extent do you design online materials for supporting your students? (no, 1, 2, 3, 4, 5, large)

4. To what extent do you deal with real-world problems in project-based learning? (no, 1, 2, 3, 4, 5, large)

\subsection{ICTS: COMPLEX TOOLS}

1. To what extent do you use authoring environments to produce learning material for your students?

(no, 1, 2, 3, 4, 5, large)

2. To what extent do you use authoring environments to produce online material for your students?

(no, 1, 2, 3, 4, 5, large)

3. Do you use a platform to manage, monitor, or assess the progress of your students?

a. Yes/ b. No

4. To what extent do you use ICTs to communicate with your students? (no, 1, 2, 3, 4, 5, large)

5. Do you use a platform to support your students' learning?

a. Yes/ b. No

6. Do you use social networks to interact with your students and colleagues?

a. Yes/ b. No 
7. To what extent do you use open educational resources?

(no, 1, 2, 3, 4, 5, large)

8. Do you use ICTs to collaborate with other schools?

a. Yes/ b. No

\subsection{ORGANISATION AND ADMINISTRATION: COLLABORATIVE GROUPS}

1. Do you organize computers and other resources within the classroom to support collaborative activities?

a. Yes/ b. No

2. Do you create a learning environment to manage project-based activities?

a. Yes/ b. No

3. Do you organize the classroom to support groups working with different tools?

a. Yes/ b. No

4. To what extent can you define the requirements of a classroom setting to match the needs of groups working collaboratively?

(no, 1, 2, 3, 4, 5, large)

\subsection{TEACHER PROFESSIONAL LEARNING: MANAGE AND GUIDE}

1. Do you share digital resources with you colleagues?

a. Yes/ b. No

2. Do you collaborate with outside experts?

a. Yes/ b. No

3. Are you a member of a teachers' virtual community of practice?

a. Yes/ b. No

4. To what extent do you use the Internet for your professional learning? (no, 1, 2, 3, 4, 5, large)

\section{UNIT 3. "KNOWLEDGE CREATION"}

\subsection{UNDERSTANDING ICTS IN EDUCATION: POLICY INNOVATION}

1. How do you think that you could contribute to implement or modify an ICT policy in the school?

a. (very little, 1, 2, 3, 4, 5, radically)/ b. I have no precise idea

2. How do yo contribute to the discussion of policy for introducing ICTs in the school?

a. (very little, 1, 2, 3, 4, 5, radically)/ b. I have no precise idea

3. How did this policy to change your practice in the classroom?

a. (very little, 1, 2, 3, 4, 5, radically)/ b. I have no precise idea

\subsection{CURRICULUM AND ASSESSMENT: KNOWLEDGE SOCIETY SKILLS}

1. Do you intentionally use ICTs to improve students' communication skills?

a. Yes/ b. No

2. Do you intentionally use ICTs to help students find ideas and information?

a. Yes/ b. No 
3. Do you intentionally use ICTs to help students to collaborate?
a. Yes/ b. No

4. Do you intentionally use ICTs to help students share knowledge?

a. Yes/ b. No

5. Do you help students acquire information problem-solving skills?

a. Yes/ b. No/ c. The question is not clear to me

6. Do you use web 2.0 to assess higher order skills (creativity, problem solving, collaboration, etc.)?

a. Yes/ b. No/ c. The question is not clear to me

\subsection{PEDAGOGY: SELF-MANAGEMENT}

1. Do you design online activities that engage students in problem-solving or artistic creation?
a. Yes/ b. No

2. Do you help students in multimedia production?

a. (very little, 1, 2, 3, 4, 5, very much)

3. How important is the creation of students' new knowledge?

a. (very little, 1, 2, 3, 4, 5, very much)

4. Do you reflect with your students on their own learning?

a. (very little, $1,2,3,4,5$, very much)

\subsection{ICTS: PERVASIVE TECHNOLOGY}

1. Do you design online learning environments to support your students' learning?
a. Yes/ b. No

2. Do you use social networks to support your students' learning?
a. Yes/ b. No

3. Do you use web 2.0 to support students' in creating their own digital products? a. Yes/ b. No/ c. The question is not clear to me

4. Is your classroom involved in learning projects with other schools using online communication?
a. Yes/ b. No

\subsection{ORGANISATION AND ADMINISTRATION: LEARNING ORGANIZA- TIONS}

1. Do you organize the classroom as a learning community?
a. Yes/ b. No

2. Do you create a learning environment to support collaborative projects with other schools?
a. Yes/ b. No

3. Do you use the web to collaborate with your colleagues systematically?
a. Yes/ b. No

4. Do you share your materials and projects with other teachers?
a. Yes/ b. No 


\subsection{TEACHER PROFESSIONAL LEARNING: TEACHER AS A MODEL LEARNER}

1. Do you play a key role in introducing ICTs into your school?

a. Yes/ b. No

2. Do you are considered a leader in introducing ICTs in Education?

a. Yes/ b. No

3. Do your colleagues consult with you to introduce ICTs in their own teaching? a. Yes/ b. No

4. Do you teach in teachers' in-service courses?

a. Yes/ b. No

5. Do you participate in professional virtual communities?

a. Yes/ b. No

\section{Digital Education: MOOC Platform in RuNet}

Fast development and diffusion of information and communication technologies (ICT) have had a significant impact on the change of the traditional model of educational systems and teaching and learning methods. The development of distance education technologies and employment of digital education content expand the access to higher education and contribute to the improvement of its quality, which is particularly important for developing countries. Massive Open Online Courses (MOOC), recognized as one of 30 the most promising trends in education until 2028 among, opened up new possibilities in the field of distance education.

Russian-speaking MOOC on Coursera (Coursera) - an educational platform that offers free online courses: the partners include leading universities and organizations around the world (Coursera, 2016).

Electronic courses IITE UNESCO (UNESCO, 2016c) - open courses portal in Russian and English languages: the course "ICT in education" (in Russian) for teachers of the Russian language space is created on the basis by the same study (books materials).

National Open University - INTUIT (INTUIT, 2016):

- Courses (total: 548).

- Video courses (total: 174).

- Certification (total: 57 ).

- Intel Academy (total: 20).

- Microsoft Academy (total: 101).

Courses in IT:

- Algorithms and discrete structures.

- Hardware.

- Database.

- Security. 
- Graphic and Design.

- Internet technologies.

- Artificial Intelligence and Robotics.

- Computer graphics.

- Mobile technology.

- OS.

- Office technology.

- Programming.

- Software.

- CAD.

- Network technologies.

- Supercomputer technologies.

Universarium - inter-university e-learning platform (Universarium, 2016): open Online Courses Russian universities.

Lectorium - educational project (Lektorium, 2016): open Video Courses University Teachers.

Rusere - Russian-language electronic resources in education (RUSERE, 2016): courses ICT competence of teachers.

\section{Digital Education: MOOC for Teachers}

Since September 2014 IITE shoves in MOOC work "ICT in Education" for mass selfeducation teachers in Russia of the ICT competence.

The core of the course is the book "ICT in Education", published 2013. The book is presented in electronic library of the UNESCO IITE in the public domain and is made in the form of a platform «e-book» (UNESCO, 2016d). The electronic textbook integrated hyperlinks to all the important e-books from UNESCO IITE electronic library and open online courses IITE. The electronic textbook "ICT in education" provided with questions to the topics, practical tasks for independent work of a web user.

For Russian teachers deployed portal (RUSERE, 2016) as an open resource in domain RU. This portal is the medium for cooperation in the design of the course "ICT in Education" various regional training centers proposed a single program. The program provides a sample matrix of online course design, using different models of his presentation: a model of a distance course IITE, model «e-book» and model on Web3.0 portal (RUSERE, 2016; ACADEMIA, 2016).

A total of presented three MOOC for teachers (RUSERE, 2016):

- Electronic textbook in information-educational space of school. The goal of the course - to obtain new professional competencies of teachers needed for the activity in the information-educational space of the school, the formation skills of teachers to use e-books in lessons. 
- New ICT competence of teachers. The goal of the course - the formation of the total for all of the readiness of teachers to integrate learning technologies on the basis by ICT resources in teaching practice.

- Construction masks on an open platform Open edX. The course is designed to train teachers design their open training online modules for students on the topics on the subject of the program. Upon completion of training, the teacher to create copyrights online courses on an open platform Open edX and provide an opportunity for students to develop remotely additional modules on the program of the subject matter.

\section{Conclusion}

The methodological approach proposed in this document explains the stages of the UNESCO ICT-CFT adaptation process; suggests guidelines to determine the appropriate strategies and policies for the development of ICTs in education, and identifies the resources needed for the successful implementation of the ICT-CFT to the local context.

\section{References}

ACADEMIA (2016). E-Learning. (In Russian. ACADEMIA: АПК и ППРО. Электронное обучение). www.e-learning . apkpro.ru

Badarch, D. (Ed.) (2013). Information and Communication Technologies in Education: A Monograph. UNESCO Institute for Information Technologies in Education, Moscow. (In Russian. Информационные и коммуникационные технологии в образовании: монография. Под.ред.: Бадарча Дендева. ИИТО ЮНЕСКО, Москва). http://iite.unesco.org/pics/publications/ru/files/3214728.pdf

Coursera (2016). https : //www . coursera . org/courses? orderby=upcoming\&lngs=ru

INTUIT (2016). National Open University. Studies, Courses. (In Rassian. ИНТУИТ: Национальный открытый университет. Учёба, курсы). http://www . intuit.ru/studies/courses

Lektorium (2016). Educational Project. (In Russian. ЛЕКТОРИУМ: Просветительский проект). https://www.lektorium.tv/

Midoro, V. (2013). Guidelines on adaptation of the UNESCO ICT Competency Framework for Teachers. UNESCO Institute for Information Technologies in Education, Statistics of Russia. Moscow. http://iite.unesco.org/publications/3214726/

RUSERE (2016). Russian Electronic Resources in Education. (In Rissian. RUSERE: Русскоязычные электронные ресурсы в образовании). http://rusere.ru

UNESCO (2011). UNESCO ICT Competency Framework for Teachers. UNESCO, Paris. http://unesdoc. unesco.org/images/0021/002134/213475e.pdf http://ru.iite.unesco.org/publications/3214694/

UNESCO (2016a). UNESCO Institute for Information Technologies in Education. http://iite.unesco.org/

UNESCO (2016b). UNESCO Institute for Information Technologies in Education: IITE Publications. http://iite.unesco.org/publications/

UNESCO (2016c). UNESCO Institute for Information Technologies in Education: UNESCO IITE E-Courses. http://lms.iite.unesco.org/

UNESCO (2016d). E-Book. (In Rassian. ЮНЕСКО. Электронные учебники. Информационные и коммуникационные технологии в образовании: монография). http://ebook.iite.unesco.org

Universarium (2016). Inter-University e-Learning Platform. (In Rissian. УНИВЕРСАРИУМ - Открытая система электронного образования). http://universarium.org 
M.S. Tsvetkova, Professor of the Russian Academy of Natural Sciences, $\mathrm{PhD}$ in pedagogic science, prize-winner of competition "The Teacher of Year of Moscow" (1998), main expert of state projects of school education informatization in the Ministry of Education of the Russian Federation (2001-2005), the expert of the World Bank project "Informatization of Education System". Since 2002 she is a member of the Central methodical Commission of the Russian Olympiad in Informatics, the pedagogic coach of the Russian team on the IOI. She is the author of many papers and books in Russia on the informatization of education and methods of development of talented students. Since 2013, she is the Russian team leader. 